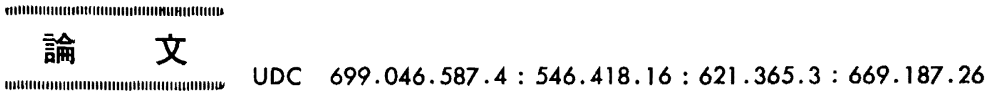

\title{
エレクトロスラグ溶解用フラックスの電導機構に関する研究*
}

\author{
荻野 和巳**. 原茂太 ${ }^{* * *} \cdot$ 橋本 英弘 ${ }^{* * * *}$

\section{Study of the Conduction Mechanism of Molten Fluxes for Electroslag Remelting}

Kazumi OGino, Shigeta Hara, and Hidehiro Hashimoto

\begin{abstract}
Synopsis:
Electrical conductivities of $\mathrm{CaF}_{2}$-based fluxes for electroslag remelting were measured and the effects of the additions on the conductivity of $\mathrm{CaF}_{2}$ melt were studied. From the results, conduction mechanism of $\mathrm{CaF}_{2}$-based melts were discussed in the term of molar conductivity. The additions of alkali earth metal fluorides and oxides, such as $\mathrm{MgF}_{2}, \mathrm{BaF}_{2}, \mathrm{MgO}, \mathrm{CaO}$ and $\mathrm{BaO}$, varied the molar conductivities of $\mathrm{CaF}_{2}$-based melts in accordance with the intensity of cation-anion attraction. It seems that those additions have a tendency to make an ionic pair in the melts. The additions such as $\mathrm{Al}_{2} \mathrm{O}_{3}, \mathrm{TiO}_{2}$ and $\mathrm{ZrO}_{2}$, may react with fluorine ions to make oxy-fluoride complex ions and then remarkable decreace of electrical conductivity by those additions can be explained.
\end{abstract}

1. 緒

言

エレクトロスラグ精鍊 (ESR) 用フラックスとして通 常フッ化カルシウム $\left(\mathrm{CaF}_{2}\right)$ を主成分とする合成スラグ が用いられている，しかし， $\mathrm{CaF}_{2}$ 在単独で使用するこ とは比較的少なく，種々な添加物を加えて用いられる. これは $\mathrm{CaF}_{2}$ に対し適当な添加物を加えて精鍊作用を強 化することに共に，単体では鋼溶解用としては電導度が 高すぎて十分な溶解効率を得難いという久点を添加物の 作用で適切な電導度の值（6〜3 $\mathrm{mho} / \mathrm{cm} ）$ にまで低下さ せ克服するためである。

ESR 用フラックスの電導度はこの溶解プロセスの発 熱機構と直接関係する重要な性質であり, 諸家によつて 広く研究されてきた。しかしながら，スラグに要求され る種々の物性值の中でも電導度の測定値は研究者による 相湋が著しいものの1つである.これは高温における $\mathrm{CaF}_{2}$ を主成分とする融体は高温绐金スラグ中でもとく に電導性が良好で，また反応性にも富むことから十分な 測定精度を確保することが困難なためである。しかし， すでに報告した交流 4 端子法1)を用いることによつて， このような融体の電導度の正確な測定が可能となつた。

本趣ではこの交流4端子法を用いて $\mathrm{CaF}_{2}$ を主成分と する ESR 用フラックスの電導度を正確に決定与ると共
にその電導機構について考察した. その結果を報告す る.

\section{2. 実験}

\section{$2 \cdot 1$ 測定装置および方法}

交流 4 端子法による高温融体の電導度の測定装置およ びその方法に関しては别報1)においてすでに詳細に記述 したので省略するが，本研究で用いた測定条件を一括し て Table 1 亿示す. 測定は 1 組成について原則として 2 回以上の測定を繰返し，これら数回の測定によつて得 られた測定点を用いてフラックスの電導度と温度との関 係を决定した。

Table 1. Experimental conditions for measurements of electrical conductivities of calcium fluoride based fluxes for electroslag remelting.

\begin{tabular}{|l|l|}
\hline method & four terminal method with alternative current \\
\hline applied frequency & \multicolumn{1}{|c|}{$1 \mathrm{kHz}$} \\
\hline Crucible & molybdenum crucible with $39 \mathrm{~mm}^{+10}$ and $50 \mathrm{~mm}$ height \\
\hline electrode & $1 \mathrm{~mm}^{+}$tungs ten rod $\times 4$ \\
\hline atmosphere & urtra pure argon (99.999:up ) \\
\hline sample & $\begin{array}{l}\text { mixture of chemically pure reagents, dehydrated by } \\
\text { vacuum heating }\end{array}$ \\
\hline
\end{tabular}

* 昭和 51 年 11 月本会講演大会にて発表 昭和 52 年 5 月 25 日受付 (Received May 25, 1977)

** 大阪大学工学部 工博 (Faculty of Engineering, Osaka University)

*** 大阪大学工学部 (Faculty of Engineering, Osaka University, Yamadakami Suita 565)

**** 大阪大学大学院 (現 日本ルッボ(株)) (Graduate School, Now Nikkan Ltd.) 


\section{$2 \cdot 2$ セル定数の決定}

前報において1) $\mathrm{CaF}_{2}$ の $1500^{\circ} \mathrm{C}$ および $1600^{\circ} \mathrm{C}$ に おける比電導度の值を $6.15 \mathrm{mho}-\mathrm{cm}$ および $6.40 \mathrm{mho} /$ $\mathrm{cm}$ と定めた。 そこで本報においては添加物の効果をよ り正確に把握するためにこの值を基準として高温 $\mathrm{CaF}_{2}$ 浴を用いてセル定数を定めた. セル定数は試料の測定前 後について調べることを原則としたが，その值は測定前 後で $\pm 0.5 \%$ を越えて変化することはなかつた。

\section{$2 \cdot 3$ フラックス}

工業的に使用されている鋼溶解用実用フラックスは, $\mathrm{CaF}_{2}$ を主成分とし，これにフッ化物または酸化物を加 えた合成スラグである，そこで本研究では $\mathrm{CaF}_{2}$ を主成 分としそれに添加物を加えた 2 成分系に限定して測定を 行なつた。試料は特級試薬を配合した合成スラグで，溶 解前に真空加熱によつて十分脱水した．配合組成と実験 終了後の組成との間には以前の研究2)において若干の差 異が存在することが認められたが，測定值に影響を与え ないと考えられたので無視した.

\section{3. 結}

\section{果}

$\mathrm{CaF}_{2}-\mathrm{CaO}$ 系融体の電導度の温度による変化を Fig. 1 に示す。この系は実用フラックス ANF-IP $\left(\mathrm{CaF}_{2}\right.$ $5 \% \mathrm{CaO})$, や $\mathrm{ANF}-7\left(\mathrm{CaF}_{2}-20 \% \mathrm{CaO}\right)$ などの基本と

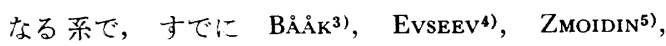
WINGERHAGER $5^{6)}$, MITCHELL ら7)によつて研究され てきた。本結果は EVSEEv4), や MITCHELL ら ${ }^{7)}$ の值と

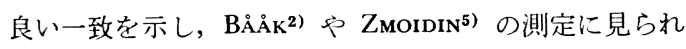
る $\mathrm{CaO}$ を少量加えた場合の急激な電導度の上昇は観察 されなかつたが, 少量の $\mathrm{CaO}$ を加えた場合若干電導度 が增加する傾向は存在する. WINTERHAGER ら6)の結果 は他の測定者の值と比して少し低值を与えている. 本 系で特徽的なことは $37.3 \mathrm{~mol} \% \mathrm{CaO}$ を含むフラックス

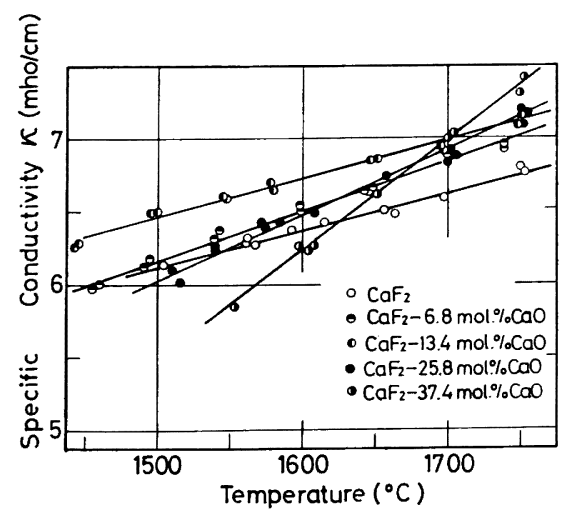

Fig. 1. Electrical conductivity of $\mathrm{CaF}_{2}-\mathrm{CaO}$ melts.
で見られるように $\mathrm{CaO}$ が高くなると比電導度の温度依 存性に変化が生ずることにある. 同様に添加物によつて 比電導度の 温度依存性の変化する系としては Fig. 2 に 示す $\mathrm{CaF}_{2}-\mathrm{MgO}$ 系, $\mathrm{CaF}_{2}-\mathrm{MgF}_{2}$ 系, Fig. 3 に示す $\mathrm{CaF}_{2}-\mathrm{BaO}$ 系, $\mathrm{CaF}_{2}-\mathrm{BaF}_{2}$ 系がある. 亦なわち，この 傾向はアルカリ土類金属のフッ化物または酸化物を添加 した場合に共通する特徵であるように思われる。しか し，これらの添加物は $1600 \sim 1700^{\circ} \mathrm{G}$ における $\mathrm{CaF}_{2}$ の比電導度の值は大きく変化させる効果はない. これに 対し， $\mathrm{CaF}_{2}$ 融体中では錯イオンを形成すると考えられ る $\mathrm{Al}_{2} \mathrm{O}_{3}, \mathrm{ZrO}_{2}, \mathrm{TiO}_{2}$ などを含む系では少し異なる挙 動を示す. Fig. 4 には $\mathrm{CaF}_{2}-\mathrm{Al}_{2} \mathrm{O}_{3}$ 系融体の比電導度 の温度による变化を示す. この系は実用 ESR 用フラッ クスとして最も広く用いられている ANF-6 $\left(\mathrm{CaF}_{2}-30\right.$ $\left.\mathrm{wt} \% \mathrm{Al}_{2} \mathrm{O}_{3}\right)$ の基本系として重要であり, 多くの研究者 によつて研究されてきた4) 、 . 本実駗において得られた この系の比電導度の值は EVSEEV の值 ${ }^{4)}$ と良い一致を示

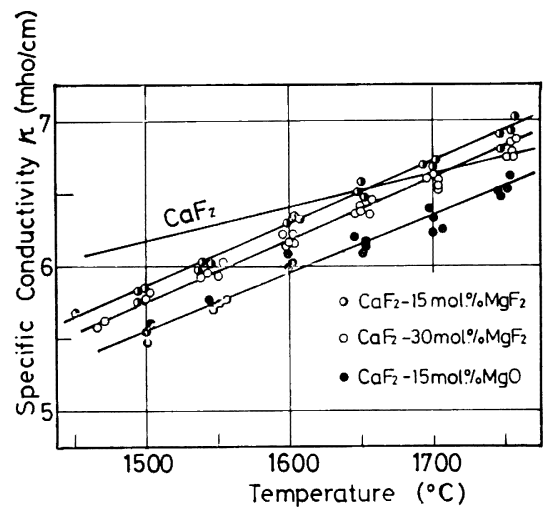

Fig. 2. Electrical conductivities of $\mathrm{CaF}_{2}-\mathrm{MgF}_{2}$ and $\mathrm{CaF}_{2}-\mathrm{MgO}$ melts.

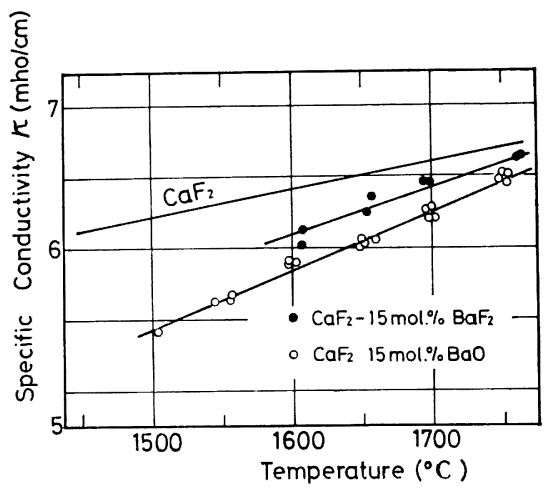

Fig. 3. Electrical conductivities of $\mathrm{CaF}_{2}-\mathrm{BaF}_{2}$ and $\mathrm{CaF}_{2}-\mathrm{BaO}$ melts. 


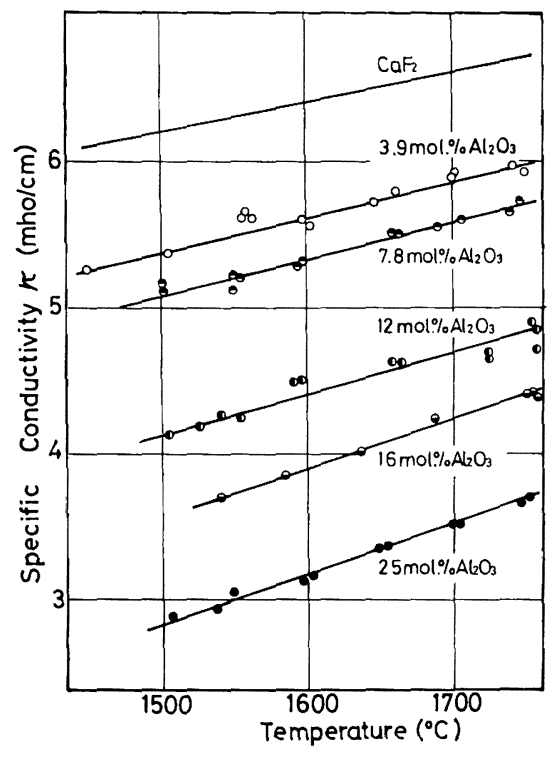

Fig. 4. Electrical conductivities of $\mathrm{CaF}_{2}-\mathrm{Al}_{2} \mathrm{O}_{3}$ melts.

し, Mitchell and Joshi の值7)に比して少し高值を示 した. $\mathrm{CaF}_{2}$ 融体への $\mathrm{Al}_{2} \mathrm{O}_{3}$ 添加の効果は比電導度の 低下に対しては大きな寄与を示すが，その温度依存性を ほとえど变えないことが特徵的である. 同様な 挙動は $\mathrm{CaF}_{2}-\mathrm{ZrO}_{2}$ 系および $\mathrm{CaF}_{2}-\mathrm{TiO}_{2}$ 系についても期待さ れる、これらの系について電導度の測定を試みた。しか しながら， $\mathrm{CaF}_{2}$ に対し $\mathrm{ZrO}_{2}$ や $\mathrm{TiO}_{2}$ を加えた 2 元系 の場合, 測定を比較的低温のみに限定すれば比電導度の 測定は可能であるが， $1600^{\circ} \mathrm{C}$ 以上の高温では固相が電 極の表面に析出付着し，測定を継続することが困難であ つた。また低温における比電導度の值も表面が浴内部に 比して著しく低いという現象が見られた，そこで，高温 で溶解した試料を凝固し，その表面部分を取つて粉末 $\mathrm{X}$ 線回折によつて調べた. その結果，フラックス浴の表 面に高融点化合物 $\mathrm{CaO} \cdot \mathrm{ZrO}_{2}$ (融点 $2350^{\circ} \mathrm{C}$ ) および $\mathrm{CaO} \cdot \mathrm{TiO}_{2}\left(1915^{\circ} \mathrm{C}\right)$ の存在が認められた. そこで， この系では次のような反応が進行して表面に $\mathrm{CaO}$ が析 出し測定を妨げているものと推察された.

$$
\begin{aligned}
& 2 \mathrm{CaF}_{2}+\mathrm{ZrO}_{2} \rightarrow \mathrm{ZrF}_{4}(\mathrm{~g}) \uparrow+2 \mathrm{CaO}(\mathrm{s}) \\
& 2 \mathrm{CaF}_{2}+\mathrm{TiO}_{2} \rightarrow \mathrm{TiF}_{4}(\mathrm{~g}) \uparrow+2 \mathrm{CaO}(\mathrm{s})
\end{aligned}
$$

この反応によつて生成する $\mathrm{CaO}$ の量は高温になるほ ど大きく，生成速度がスラグ浴中への溶解速度に比して 大きいために高温度ではとくに顕著な固相の析出が見ら れると考えられる. そこで，この系の融体に前もつて $\mathrm{GaO}$ を加えることによつて（1)，(2) の反応の進行を

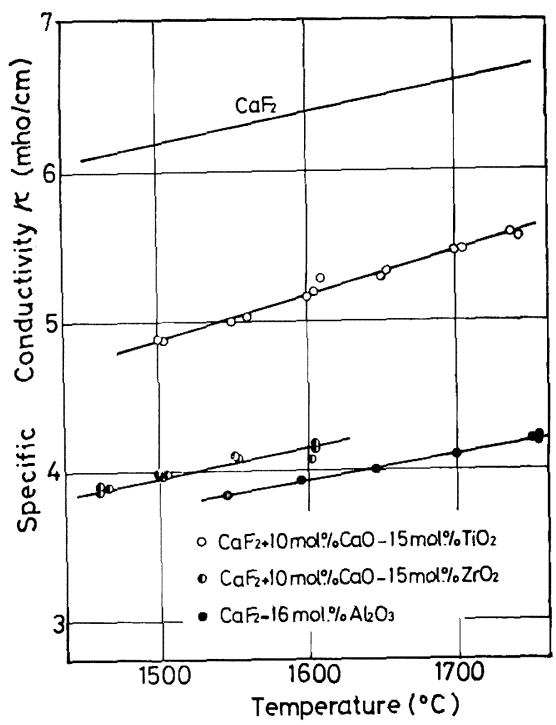

Fig. 5. Electrical conductivities of $\mathrm{CaF}_{2}-\mathrm{CaO}-$ $\mathrm{TiO}_{2}$ and $\mathrm{CaF}_{2}-\mathrm{CaO}-\mathrm{ZrO}_{2}$ melts.

防ぎ，固相の析出を扮さえることを試みた．この目的で 融体に $10 \mathrm{~mol} \%$ の $\mathrm{CaO}$ を加えた結果，固相の析出は なくなり，またスラグ浴の表面と内部との電導度の差異 も消失した．Fig. 5 には $10 \mathrm{~mol} \% \mathrm{CaO}$ を含む $\mathrm{CaF}_{2-}$ $\mathrm{ZrO}_{2}$ および $\mathrm{CaF}_{3}-\mathrm{TiO}_{2}$ 系スラグの電導度の温度変化 を示す. $\mathrm{ZrO}_{2}$ や $\mathrm{TiO}_{2}$ の添加は $\mathrm{Al}_{2} \mathrm{O}_{3}$ の場合と同様, 電導度の低下に大きく寄与するが，その温度依存性は $\mathrm{CaF}_{2}$ の場合と変らない.

以上の結果に基づいて $1600^{\circ} \mathrm{C}$ における $\mathrm{CaF}_{2}$ の比

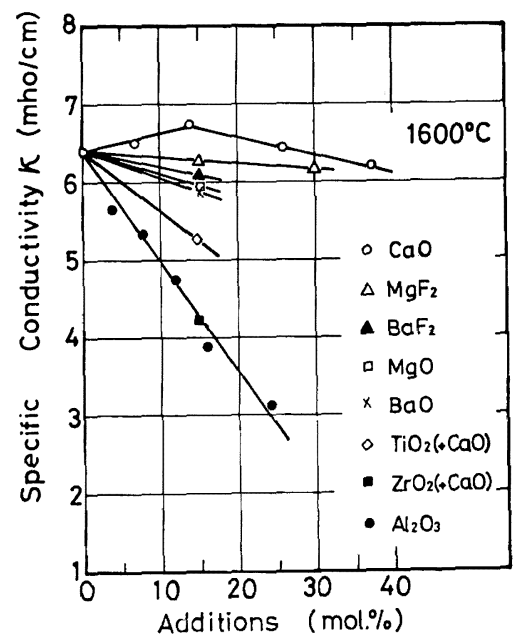

Fig. 6. Change of electrical conductivities of $\mathrm{CaF}_{2}$ with additions at $1600^{\circ} \mathrm{C}$. 


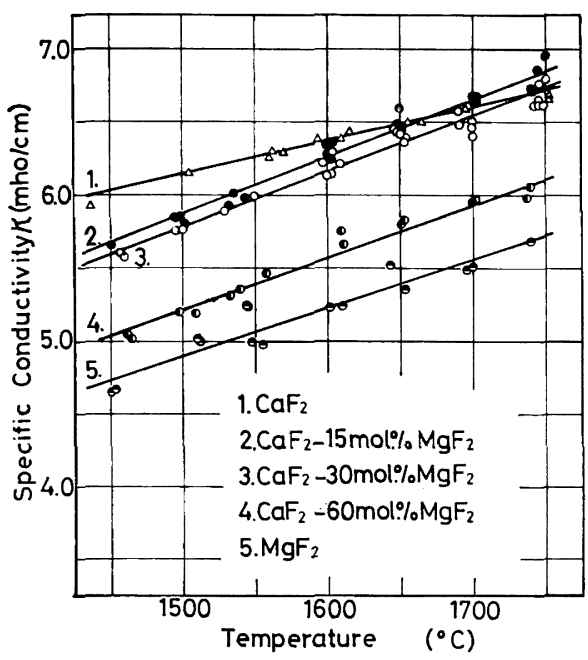

Fig. 7. Effect of temperature on electrical conductivities of $\mathrm{CaF}_{2}-\mathrm{MgF}_{2}$ melts.

電導度に及ぼす添加物の影響を示すと Fig. 6 のようで ある・

つきに $\mathrm{CaF}_{2}-\mathrm{MgF}_{2}$ 系について 全組成範囲にわたつ て比電導度の温度变化を調べた. その結果は Fig. 7 に 示す.この系は $\mathrm{CaF}_{2}$ と共通アニオンを有し, カチオン のみをことにする采であり，全組成範囲にわたつて測定 が可能である. $\mathrm{CaF}_{2}$ に $\mathrm{MgF}_{2}$ を加えると Fig. 7 に示 すように比電導度は低下し，また比電導度の温度依存性 は大きくなる. この結果については後章で考察する.

\section{4. 考察}

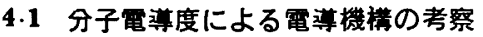

イオン性融体における電気伝導は電導イオンの移動過 程であつて, その比電導度 $\kappa$ は電導イオンの電荷 $z_{i}$, 易動度 $u_{i}$ および $1 \mathrm{cc}$ 中に含まれる電導イオンの数 $n_{i}$ によつて（3）式のように表現される.

$$
\kappa=\Sigma n_{i}\left(z_{i e}\right) u_{i}
$$

\section{ここで $e$ : 単位電荷}

そこでこの融体中に含まれるイオンの解離状態がわか れぼ比電導度 $\kappa$ は易動度 $u_{i}$ のみの関数となり, 電導機 構は当量電導度を用いて考察することが便利である. し かし，アルカリ土類金属のハロゲン化物 $\mathrm{MX}_{2}$ について はどのような解離状態を取るかは十分に知られていな い.そこで本研究では分子電導度による整理を試みた。 Fig. 8 には比電導度 $\kappa$, 当量電導度 $\lambda$ および分子電導度 $\Lambda$ の関係を示している. 比電導度 $\kappa$ は融体中に $1 \mathrm{~cm}^{3}$ の 立方体を考えた場合，平行する 2 面間の溶液抵抗の逆数

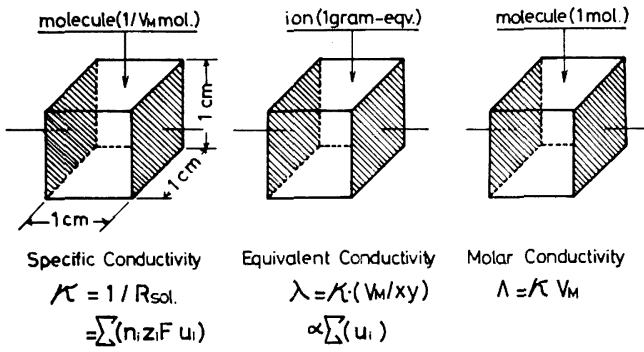

$\left(M_{x} N_{y}\right) \rightarrow \times M^{y+}+Y N^{x-}$

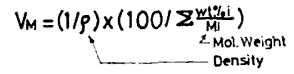

Fig. 8. Relation between specific conductivity and molar conductivity.

で与えられる. また，この立方体中に $1 \mathrm{~g}$ 当量のイオン

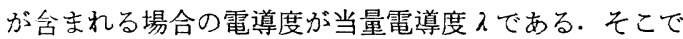
(4) 式で示される解離反応が完全に右方向に進行してい るとすれば当量電導度 $\lambda$ は比電導度 $\kappa$ およびその融体の 分子容 $V_{M}(\mathrm{cc} / \mathrm{mol})$ でもつて (5) 式のように与えら れる。

$$
\begin{aligned}
& M_{x} N_{y} \rightarrow x M^{y+}+y M^{x-} \\
& \lambda=\kappa\left(\frac{V_{M}}{x_{y}}\right) \cdots \cdots \cdots \cdots \cdots \cdots \cdots \cdots \cdots \cdots
\end{aligned}
$$

また分子電導度 $\Delta$ はこの立方体中に $1 \mathrm{~mol}$ の分子が 含まれる場合の電導度で（6）式で表現される.

$$
\Lambda=\kappa V_{M}
$$

融体の分子容 $V_{M}$ はその融体の密度 $\rho$ から（7）式に よつて計算することができる.

$$
\begin{gathered}
V_{M}=\frac{1}{\rho} \times \frac{100}{\sum\left(i \% / M_{i}\right)} \cdots \ldots \ldots \ldots \ldots \ldots \\
\text { ここで } \quad \rho \text { 一融体の密度 }(\mathrm{g} / \mathrm{cc}) \\
i \%-i \text { 成分の重量パーセント } \\
M_{i}-i \text { 成分の分子量 }
\end{gathered}
$$

そこで分子容の計算にあたつてはその融体の密度を知 ることが必要である. 融体の $1700^{\circ} \mathrm{G}$ における密度は 次のようにして決定した. $\mathrm{CaF}_{2}-\mathrm{CaO}$ 系掞よび $\mathrm{CaF}_{2-}$ $\mathrm{Al}_{2} \mathrm{O}_{3}$ 系融体の密度は著者らの $1450 \sim 1600^{\circ} \mathrm{C}$ におけ る密度の実測值 2 を $1700^{\circ} \mathrm{C}$ まで外挿して求めた. $\mathrm{CaF}_{2}-\mathrm{MgF}_{2}$ 系, $\mathrm{CaF}_{2}-\mathrm{BaF}_{2}$ 系については著者らの検討 の結果, 寸なわちフッ化物ーフッ化物系は分子容の加成 性がかなり広範囲に認められることから, 著者らの測定 したアルカリ土類金属フッ化物の密度值视艺用い，分子 容の加成性を仮定して算出した. $\mathrm{CaF}_{2}-\mathrm{MgO}$ 采, $\mathrm{CaF}_{2}-$ $\mathrm{BaO}$ 系については同じアルカリ土類金属酸化物を含む $\mathrm{CaF}_{2}-\mathrm{CaO}$ 系において分子容の加成性が成立すること 
から，分子容の加成性を仮定して算出した．この場合，

$\mathrm{MgO}$ と $\mathrm{BaO}$ の分子容としては BOCKRIS らの推定値9) $V_{\mathrm{MgO}}=15.82 \mathrm{cc} / \mathrm{mol} \quad\left(\rho_{\mathrm{MgO}}=2.55 \mathrm{~g} / \mathrm{cc}\right)$ 々 $V_{\mathrm{BaO}}=$ $28.11 \mathrm{cc} / \mathrm{mole}\left(\rho_{\mathrm{BaO}}=5.46 \mathrm{~g} / \mathrm{cc}\right)$ を採用した.

$\mathrm{CaF}_{2}-\mathrm{CaO}-\mathrm{TiO}_{2}$ 系および $\mathrm{CaF}_{2}-\mathrm{CaO}-\mathrm{ZrO}_{2}$ 系の密 度 $\rho$ については EvSEEV ら10)の与えた式を少し変形した

(8) 式によつた.

$$
\begin{aligned}
& \frac{100}{\rho}=0.416\left(\% \mathrm{CaF}_{2}\right)+0.375(\% \mathrm{CaO}) \\
& +0.370\left(\% \mathrm{ZrO}_{2}\right)+0.462\left(\% \mathrm{TiO}_{2}\right) \cdots \cdots
\end{aligned}
$$

(単位 wt $\%$ )

以上のようにして 推定した $1700^{\circ} \mathrm{C}$ における融体の 密度および分子容の Table 2 に示す.

Fig. 9 には融体中において錯イオンを抢成しないと考 えられる添加物を加えた場合の $1700^{\circ} \mathrm{C}$ における分子

Table 2. Densities and molar volume for fluxes

\begin{tabular}{|c|c|c|}
\hline Flux & density $(g / c c)$ & molar volume (cc/mol) \\
\hline $\mathrm{CaF}_{2}$ & 2.407 & 32.44 \\
\hline $\mathrm{CaF}_{2}-3.9 \mathrm{~mol} .2 \mathrm{Al}_{2} \mathrm{O}_{3}$ & 2.394 & 33.00 \\
\hline $\mathrm{CaF}_{2}-7.8 \mathrm{~mol} \cdot \mathrm{XAl}_{2} \mathrm{O}_{3}$ & 2.397 & 33.35 \\
\hline $\mathrm{CaF}_{2}-11.9 \mathrm{~mol}^{2} . \mathrm{xAl}_{2} \mathrm{O}_{3}$ & 2.414 & 33.55 \\
\hline $\mathrm{CaF}_{2}-16.1 \mathrm{~mol} . \mathrm{KAl}_{2} \mathrm{O}_{3}$ & 2.435 & 33.65 \\
\hline $\mathrm{CaF}_{2}-24.2 \mathrm{~mol}^{2} \mathrm{KAl}_{2} \mathrm{O}_{3}$ & 2.494 & 33.62 \\
\hline $\mathrm{CaF}_{2}-6.8 \mathrm{~mol} . \% \mathrm{CaO}$ & 2.424 & $31 . \overline{60}$ \\
\hline $\mathrm{CaF}_{2}-13.7 \mathrm{~mol} .8 \mathrm{CaO}$ & 2.434 & 30.84 \\
\hline $\mathrm{CaF}_{2}-25.7 \mathrm{mO1} .2 \mathrm{CaO}$ & 2.455 & 29.50 \\
\hline $\mathrm{CaF}_{2}-37.3 \mathrm{m01} .2 \mathrm{CaO}$ & 2.482 & 28.15 \\
\hline $\mathrm{CaF}_{2}-15 \mathrm{mo} 1.8 \mathrm{MgO}$ & 2.432 & 29.78 \\
\hline $\mathrm{CaF}_{2}-15 \mathrm{~mol} .8 \mathrm{BaO}$ & 2.701 & 33.09 \\
\hline $\mathrm{CaF}_{2}-15 \mathrm{mo}_{1.8 \mathrm{BaF}}$ & 2.697 & 34.36 \\
\hline $\mathrm{CaF}_{2}-15 \mathrm{mo1}^{2} . \mathrm{xgF}_{2}$ & 2.388 & 31.70 \\
\hline $\mathrm{CaF}_{2}-30 \mathrm{~mol}^{2}, \mathrm{xMgF}_{2}$ & 2.370 & 30.96 \\
\hline $\mathrm{CaF}_{2}-60 \mathrm{~mol} .2 \mathrm{MgF}_{2}$ & 2.328 & 29.47 \\
\hline $\mathrm{MgF}_{2}$ & 2.267 & 27.49 \\
\hline $\mathrm{CaF}_{2}-10 \mathrm{mo} 1.8 \mathrm{CaO}-15 \mathrm{~mol} .{ }^{\circ} 2 \mathrm{rO}{ }_{2}$ & 2.476 & 33.40 \\
\hline $\mathrm{CaF}_{2}-10 \mathrm{~mol} .8 \mathrm{CaO}-15 \mathrm{~mol} .8 \mathrm{TTO}_{2}$ & 2.387 & 32.15 \\
\hline
\end{tabular}
at $1700^{\circ} \mathrm{C}$.

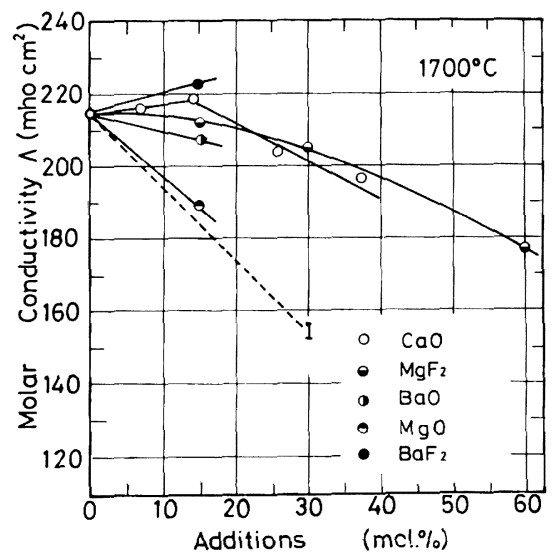

Fig. 9. Change of molar conductivities of $\mathrm{CaF}_{2}$ with additions at $1700^{\circ} \mathrm{C}$.
電導度の変化を示与. Fig.9 における破線 I は融体中の 添加物が電導に寄与せず， $\mathrm{CaF}_{2}$ 融体を希釈する效果し か持たないとした場合の分子電澊度の变化で，(9) 式で 示される.

$$
\Lambda=\Lambda_{\mathrm{CaF}_{2}} \cdot N_{\mathrm{CaF}_{2}}
$$

ここで $A_{\mathrm{CaF}_{2}}-\mathrm{CaF}_{2}$ の分子電導度

$$
N_{\mathrm{CaF}_{2}}-\mathrm{CaF}_{2} \text { のモル分率 }
$$

この結果は加えられたアルカリ土類フッ化物および酸 化物はすべて電導に関与していることを示している.そ してその寄与は $\mathrm{MgO}$ で最小， $\mathrm{BaF}_{2}$ で最大となる.こ こでとくに注目すべきは $\mathrm{CaO}$ の場合である. $\mathrm{CaO}$ は $15 \mathrm{~mol} \%$ までの添加は分子電導度を增すが，それ以上 では分子電導度を低下させる. KoJima and MAsson ${ }^{11)}$ の $\mathrm{CaF}_{2}$ 系融体の融点降下に関する研究によれば $\mathrm{CaF}_{2}$ $\mathrm{CaO}$ は固溶体を作るといわれ（固溶限は $20 \mathrm{~mol} \% \mathrm{CaO}$ と考えている)，これに刘し， $\mathrm{MgO} と \mathrm{BaO}$ とはイオン 対を作つて溶解すると考えている，したがつて $\mathrm{CaO}$ を 加えることによる 分子電導度の 增加は固体 $\mathrm{CaF}_{2}$ の電 導 ${ }^{12)}$ におけると同様に融体中における 2 個のフッ素イオ ンの占有位置が 1 個の酸素イオンによつて置換されるこ とによつて生ずるフッ素のアニオン空孔が電導に関与す るものだと考えられる.

今，融体中に働く力としてカチオンーアニオン間の静 電的引力をパラメータとして $15 \mathrm{~mol} \%$ の添加物を含む 融体の分子電導度を表わ卞と Fig. 10 のようである. こ こで $\mathrm{CaO}$ 含む系については前述のようにフッ素イオ ン空孔の電導への寄与が考えられるため $30 \mathrm{~mol} \%$ 附近 の值を採用した. 添加物による分子電導度の変化はカチ オンーアニオン間に働く静電的引力が大きくなると増加

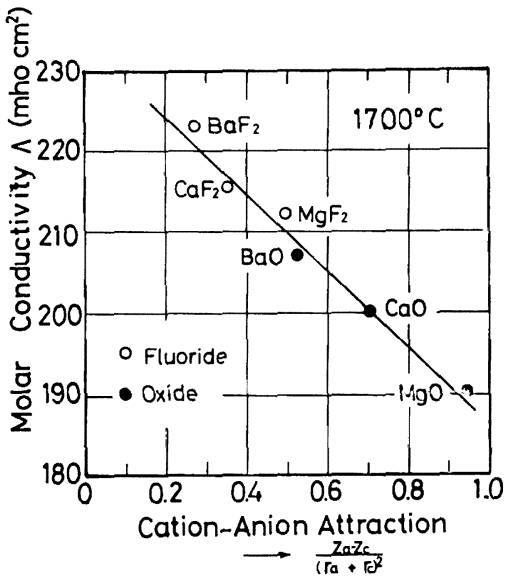

Fig. 10. Relation between molar conductivity and cation-anion attraction. 
し，このことは静電的引力の大きな添加物ほど融体中で イオン対を作つて移動する傾向が強いことと関連してい ると思われる。同様な現象は KLEMM and BILTZ ${ }^{13)}$ に よつて測定されたアルカリ金属およびアルカリ土類金属 塩化物の電導度についても見られ，アルカリ金属ではイ オン半径の 小さいものほど $\left(\mathrm{Li}^{+}>\mathrm{Na}^{+}>\mathrm{K}^{+}>\mathrm{Cs}^{+}\right.$の 順で）電導度は増大するのに対し，アルカリ土類金属で はイオン半径の大きなものほど $\left(\mathrm{Mg}^{2+}<\mathrm{Ca}^{2+}<\mathrm{Sr}^{2+}<\right.$ $\mathrm{Ba}^{2+}$ の順で) 電導度は増加することが知られる.

融体中に加えられて錯イオンを形成すると考えられる 添加物を含む系の電導度を Fig. 11 に示す.これらの系 については分子容の加成性は成立しない2)。 そこで， $\mathrm{Al}_{2} \mathrm{O}_{3}$ の希釈作用を示す Fig. 11 の線 $\mathrm{I}$ は $\mathrm{CaF}_{2}$ の部 分々子容 $\overline{V_{M}}$ を用いて (10) 式で示される.

$$
\Lambda=\kappa \overline{V_{M}} N_{\mathrm{CaF}_{2}}
$$

実測点はすべてこの希釈効果の線 (I)よりも低い值を 取る.このここは融体中に加えられた添加物は電導イ才 ンの動きを束綵する作用を有していることを示してい る. 承晶石ーアルミナ采融体に関する研究によれば14) ッ化物融体に加えられた $\mathrm{Al}_{2} \mathrm{O}_{3}$ はフッ素と反応してア ルミニウムオキシフルオライド $\left(\mathrm{Al}_{x} \mathrm{O}_{y} \mathrm{~F}_{z}^{n-}\right)$ を形成し, フッ素イオンの動きを束縛すると言われ， $\mathrm{Al}_{2} \mathrm{O}_{3} 1 \mathrm{~mol}$ に対して作用するフッ素イオンは最大 6 当量であると考 えられている. 今, 融体中におけるフッ素およびカルシ ウムイオンの輪率をそれぞれ 0.5 とし，反応 (11) によ つてフッ素イオンがアルミニウムと結合し，電導イオン 数が隇少するとした場合分子電導度の変化は Fig. 11 の 線（II）のようである.

$$
\mathrm{Al}_{2} \mathrm{O}_{3}+6 \mathrm{~F}-\rightarrow \mathrm{AlO}_{2} \mathrm{~F}_{2}^{2-}+\mathrm{AlOF}_{4}^{4-}
$$

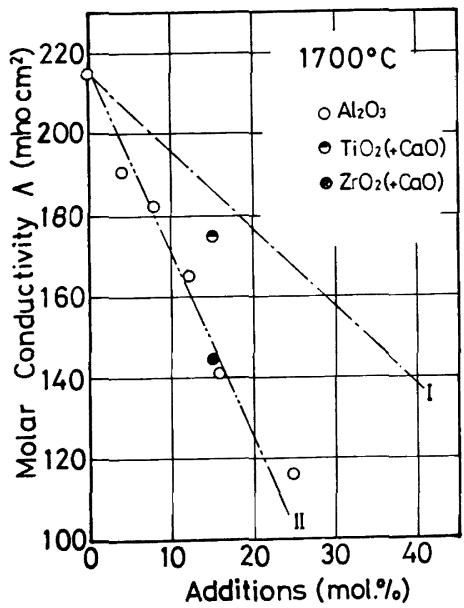

Fig. 11. Change of molar conductivities of $\mathrm{CaF}_{2}$ with additions at $1700^{\circ} \mathrm{C}$.
実測値はこのような仮定をよく満しているように思わ れる、 $\mathrm{TiO}_{2}$ や $\mathrm{ZrO}_{2}$ を含む系についてはフッ素との反 応機構が明確ではないが， $\mathrm{Al}_{2} \mathrm{O}_{3}$ の場合と類似した機構 によつて 分子電導度の低下が生ずるものだと推察され る.

\section{$4.2 \mathrm{CaF}_{2}-\mathrm{MgF}_{2}$ 系瀜体の電導度}

$\mathrm{CaF}_{2}-\mathrm{MgF}_{2}$ 系融体は共通アニオンを有し，カチオン のみ異なる融体として興味深い. この系の $1500^{\circ}$, $1600^{\circ}, 1700^{\circ} \mathrm{C}$ における分子電導度と組成との関係を Fig. 12 a に示す. ここで破線は一定温度で分子電導度の 加成性が成立するとした場合式（12）によつて示される 理想等温電導度線 (ideal conductance isotherm) を表 わしている.

$$
\Lambda_{M}=\Lambda_{\mathrm{CaF}_{2}} N_{\mathrm{CaF}_{2}}+\Lambda_{\mathrm{MgF}_{2}} N_{\mathrm{MgF}_{2}}
$$

$\mathrm{CaF}_{2}-\mathrm{MgF}_{2}$ 系において $\mathrm{MgF}_{2}$ の高濃度領域では実測 值は（12）式による値より負に偏位している。このよう な觼の偏位は多くの混合溶融塩系においても見られ，同 じ符号のイオン電荷が同じであり, 個々の単塩の当量電 導度の差が小さいものほど，この偏位は小さくなると言 われている. しかし，この負の最大偏位は約 $2 \%$ 程度で

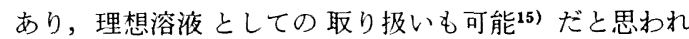
る.これに対し，とくに注目すべきは $\mathrm{CaF}_{2}$ 高濃度側に 見られる正の偏位が温度の上昇とともに顕著となること である.これに関して現在明確な説明をなし得る理論は ない。しかし，融体を短範囲には固体類似構造を取り，

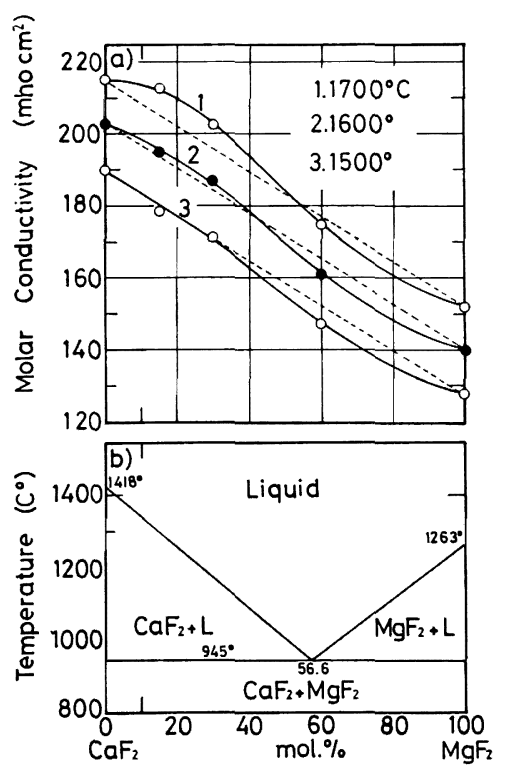

Fig. 12. Conductance isotherm (a) and phasc diagram (b) for $\mathrm{CaF}_{2}-\mathrm{MgF}_{2}$ system. 
長範囲では規則性を持たない状態であるとしたとき，次 のように考えられる.

$\mathrm{CaF}_{2}-\mathrm{MgF}_{2}$ 系状態図16) は Fig. 12 b に示すように固 体状態では $\mathrm{CaF}_{2}$ と $\mathrm{MgF}_{2}$ では固溶体を作らないこと を示している。しかし，液体状態では高温になるとと もに短範囲の規則性艺有する固体 $\mathrm{CaF}_{2}$ 類似構造中の $\mathrm{Ca}^{2+}$ イオンの位置を $\mathrm{Ca}^{2+}$ イオンよりイオン半径の小 きな $\mathrm{Mg}^{2+}$ イオンが占めることによつて加成性の線よ りも正方向に偏位することが考光られる. そこで，分子 電導度の加成性則からの偏位はこの系の共晶組成（56.6 $\mathrm{mol}_{0} \% \mathrm{MgF}_{2}$ ) 付近を境として正から負へと変化するも のと思われる.

\section{3 電章の活性化エネルギー}

本研究で取り扱つた $\mathrm{CaF}_{2}$ を主成分とする融体の比電 導度の温度による变化は高温治金スラグ融体の場合と同 様に Amhenius の式で記述できる.

$$
\kappa=A_{\kappa} \exp \left(-Q_{\kappa} / R T\right)
$$

ここで $A_{\kappa}$ : 定数

$Q_{\star}:$ 電導のみかけの活性化エネルギー (kcal/mol)

$R$ : 気体定数 $T:$ 絶対温度 $(\mathrm{K})$

分子電導度 $\Lambda$ についても同様な式が成立する.

$\Lambda=A_{\Lambda} \exp \left(-Q_{\star} / R T\right)$

$A_{A}$ : 定数
$Q_{A}:$ 分子電導の活性化エネルギー

( $\mathrm{kcal} / \mathrm{mol})$

比電導度 $\kappa$ と分子電導度 $\Lambda$ の間には (6) 式が成立し, 分子容の温度变化は (15) 式で与えられるから, 比電導 度のみかけの活性化エネルギー $Q$ 、と分子電導度のそれ $Q_{A}$ との間には (16) 式の関係が成立する.

$$
\begin{aligned}
& V=V_{0}(1+\alpha T) \cdots \\
& Q_{A}=Q_{\mathbf{c}}+\alpha R T^{2}
\end{aligned}
$$

$$
\begin{aligned}
& \text { ここで } \alpha \text { : 融体の体膨脹率 }(\mathrm{K}-1) \\
& R \text { : 気体定数 }(1.9865 \mathrm{cal} / \mathrm{mol} \mathrm{K} \text { ) } \\
& T: \text { 絶対温度 (K) }
\end{aligned}
$$

$\mathrm{CaF}_{2}$ を主成分とする融体は体膨脹率 $\alpha$ の值が大きく,

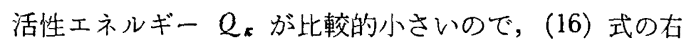
辺第 2 項の寄与は無視し得ない. (16) 式によつて求め た $1700^{\circ} \mathrm{C}$ における活性化エネルギーを Table 3 に示 す.

今融体中における電気伝導はイオンの位置の交換を伴 なう速度プロセスである，そこで電導プロセスに対して EYRING の絶対反応速度理論 ${ }^{17)}$ 它適用与ると当量電導度

\begin{tabular}{|c|c|c|c|c|c|}
\hline \multirow{2}{*}{ Flux } & \multicolumn{2}{|c|}{$\log K=a-b \times 10^{4}(1 / T)$} & \multirow{2}{*}{$Q_{r}(k c a 1 / m o l)$} & \multirow[t]{2}{*}{$\alpha R T^{2}$} & \multirow[t]{2}{*}{$\mathrm{Q}_{\mathrm{\Lambda}}(\mathrm{kcal} / \mathrm{mol})$} \\
\hline & $a$ & $b$ & & & \\
\hline $\mathrm{CaF}_{2}$ & 1.098 & 0.5517 & 2.52 & 1.54 & 4.06 \\
\hline $\mathrm{CaF}_{2}-6.8 \mathrm{~mol} . \% \mathrm{CaO}$ & 1.228 & 0.7768 & 3.55 & 1.51 & 5.06 \\
\hline $\mathrm{CaF}_{2}-13.4 \mathrm{~mol} . \% \mathrm{CaO}$ & 1.739 & 0.5807 & 2.66 & 1.38 & 4.04 \\
\hline $\mathrm{CaF}_{2}-25.8 \mathrm{~mol} . \% \mathrm{CaO}$ & 1.351 & 1.0069 & 4.61 & 1.41 & 6.02 \\
\hline $\mathrm{CaF}_{2}-37.8 \mathrm{~mol} \% \mathrm{CaO}$ & 1.783 & 1.8530 & 8.48 & 0.94 & 9.42 \\
\hline $\mathrm{CaF}_{2}-15 \mathrm{~mol}^{\prime}: \mathrm{MgF}_{2}$ & 1.359 & 1.0531 & 4.82 & 1.58 & 6.40 \\
\hline $\mathrm{CaF}_{2}-30 \mathrm{~mol}^{2} \cdot \mathrm{MgF}_{2}$ & 1.276 & 0.9086 & 4.16 & 7.56 & 5.72 \\
\hline $\mathrm{CaF}_{2}-60 \mathrm{~mol} . \% \mathrm{MgF}_{2}$ & 7.293 & 1.0219 & 4.68 & 1.48 & 6.16 \\
\hline $\mathrm{MgF}_{2}$ & 1.294 & 0.9895 & 4.53 & 1.38 & 5.91 \\
\hline $\mathrm{CaF}_{2}-15 \mathrm{~mol} . \because \mathrm{MgO}$ & 1.339 & 1.0570 & 4.83 & $(1.62)$ & $(6.45)$ \\
\hline $\mathrm{CaF}_{2}-15 \mathrm{~mol} \% \mathrm{BaF}_{2}$ & 1.319 & 1.0030 & 4.90 & 1.65 & 6.55 \\
\hline $\mathrm{CaF}_{2}-15 \mathrm{~mol} . \% \mathrm{BaO}$ & 1.324 & 1.0410 & 4.76 & $(1.62)$ & $(6.38)$ \\
\hline $\mathrm{CaF}_{2}-3.9 \mathrm{~mol}_{2} \mathrm{Al}_{2} \mathrm{O}_{3}$ & 1.084 & 0.6241 & 2.86 & 1.90 & 4.76 \\
\hline $\mathrm{CaF}_{2}-7.8 \mathrm{~mol} . \% \mathrm{Al}_{2} \mathrm{O}_{3}$ & 1.160 & 0.8133 & 3.72 & 7.41 & 5.13 \\
\hline $\mathrm{CaF}_{2}-11.9 \mathrm{~mol}^{2} \% \mathrm{Al}_{2} \mathrm{O}_{3}$ & 1.129 & 0.9097 & 4.15 & 1.39 & 6.54 \\
\hline $\mathrm{CaF}_{2}-16.1 \mathrm{~mol} . \% \mathrm{Al}_{2} \mathrm{O}_{3}$ & 1.256 & 1.2441 & 5.69 & 1.37 & 7.06 \\
\hline $\mathrm{CaF}_{2}-24.2 \mathrm{~mol} . \% \mathrm{Al}_{2} \mathrm{O}_{3}$ & 1.423 & 1.7545 & 7.99 & 1.35 & 9.34 \\
\hline $\mathrm{CaF}_{2}-10 \mathrm{~mol} . \% \mathrm{CaO}-15 \mathrm{~mol} . \% \mathrm{TiO}_{2}$ & 1.153 & 0.8222 & 3.76 & - & - \\
\hline $\mathrm{CaF}_{2}-10 \mathrm{~mol} . \% \mathrm{CaO}-15 \mathrm{~mol} . \% \mathrm{ZrO}_{2}$ & 0.967 & 0.6559 & 3.00 & - & - \\
\hline
\end{tabular}
$\lambda$ に対して (17) 式を得る.

$$
\lambda=5.18 \times 10^{18} z_{i}(D+2) l_{\imath}^{2} \exp \left(\frac{\Delta S^{\ddagger}}{R}\right) \exp \left(-\frac{\Delta H^{\ddagger}}{R T}\right)
$$

\section{ここで $z_{i}:$ 電導イオンの電荷}

Table 3. Activation energies of electrical ccnductivities for $\mathrm{CaF}_{2}$-based fluxes at $1700^{\circ} \mathrm{C}$. 
Table 4. Values of activation enthalpies $\Delta H_{*}^{*}$, activation entropies $J S_{*}^{*}$ and activation energies $\lrcorner G_{*}^{*}$ for various fluorides at melting point.

\begin{tabular}{|c|c|c|c|c|c|c|c|c|}
\hline \multirow[t]{2}{*}{ fluoride } & \multirow{2}{*}{$\begin{array}{c}\text { melting point } \\
\left({ }^{\circ} \mathrm{K}\right)\end{array}$} & \multicolumn{2}{|c|}{$\lambda=\lambda_{2} \exp \left(-E_{\lambda} / R T\right)$} & \multirow{2}{*}{$\begin{array}{l}\text { dielectric } \\
\text { constant }\end{array}$} & \multirow{2}{*}{$\begin{array}{l}\text { interatomic } \\
\text { distance }(\AA)\end{array}$} & \multirow{2}{*}{$\begin{array}{c}\Delta H^{\star} \\
(k c a l / g-i o n)\end{array}$} & \multirow{2}{*}{$\begin{array}{r}-\Delta S^{\star} \\
(e u)\end{array}$} & \multirow{2}{*}{$\begin{array}{c}\Delta G^{\star} \\
(k c a l / g-i o n)\end{array}$} \\
\hline & & $\lambda_{0}$ & $E \lambda$ & & & & & \\
\hline Lif & 1120 & 312.6 & 1783.8 & 3 & 1.95 & 1.78 & 6.85 & 9.45 \\
\hline $\mathrm{NaF}$ & 1268 & 344.7 & 2964 & 3 & 2.30 & 2.96 & 7.32 & 12.24 \\
\hline $\mathrm{KF}$ & 1131 & 402.7 & 2495 & 3 & 2.70 & 2.50 & 7.64 & 11.14 \\
\hline $\mathrm{CSF}$ & 976 & 741.8 & 3262 & 3 & 3.30 & 3.26 & 6.89 & 9.98 \\
\hline $\mathrm{MgF}_{2}$ & 1536 & 348 & 5308 & 3 & 1.42 & 5.31 & 6.76 & 15.69 \\
\hline $\mathrm{CaF}_{2}$ & 1691 & 269 & 3650 & 3 & 2.04 & 3.65 & 5.84 & 13.52 \\
\hline
\end{tabular}

$D:$ 融体の誘電率（～3 とする）

$l_{i}:$ 電導イオンの平均ジャンプ距崩の $1 / 2$

$\left.J H^{*},\right\lrcorner S^{*}$ : 電導の活性化エンタルピーとエ ントロピー

そこで本実験値を用いて $\mathrm{MgF}_{2}$ および $\mathrm{CaF}_{2}$ の融点 近傍における電導の活性化エントロピー $\left(\Delta S^{\ddagger}\right)$ および 活性化エンタルピー $\left(J H^{*}\right)$, 活性化エネルギー $\left(J G^{*}\right)$ を求めた．分子容は著者らの測定値を用い，誘電率とし ては 3 をまた分子の完全解離を仮定した．アルカリ金属 フッ化物については JANZ の集録の值18)を用いて計算を 行なつた. その結果を Table 4 に示す. $J H^{*}$ および $J G^{ \pm}$の值はアルカリ土類金属フッ化物はアルカリ金属 フッ化物に比して高い。これに対し， $\Delta S^{*}$ の值は 6〜7

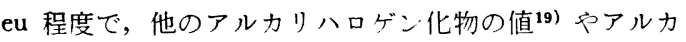
リ土類金属珪酸塩についての值 ${ }^{20)}$ と大差がない。これは 活性化状態におけるエネルギーの再配列の仕方がイオン 融体の電導に扒いては差のないことを示している，そし て融体としての特性は活性化エンタルピー項の差異に表 われている.

\section{5. 結 論}

$\mathrm{CaF}_{2}$ を主成分とする $\mathrm{ESR}$ 用フラックスの比電導度 を $1450 \sim 1750^{\circ} \mathrm{C}$ の間で交流 4 端子法を用いて 测定し たそその結果，アルカリ土類金属フッ化物および酸化物 を添加した場合, $1700^{\circ} \mathrm{C}$ 附近の比電導度を変化させな いことを示した．しかし，その温度依存性は变化した。 これに対し融体中で錯イオンを形成する酸化物 $\mathrm{Al}_{2} \mathrm{O}_{3}$, $\mathrm{ZrO}_{2}, \mathrm{TiO}_{2}$ などの添加は比電導度を低下させる効果を 持つている. 分子電導度に基づいて電導機構を考察した 結果, アルカリ土類金属フッ化物, 酸化物添加の効果は カチオンーアニオン間に働く静電的引力の大なる添加物 ほど分子電導度の低下に対する寄与は大きく, このこと はこれら添加物が融体中でイオン対を作る傾向が強いこ とを示している. $\mathrm{Al}_{2} \mathrm{O}_{3}, \mathrm{ZrO}_{2}, \mathrm{TiO}_{2}$ などの添加によ る分子電導度の低下は, 添加物が融体中で, オキシフル
オライド錯イオンを形成する結果として電導に関与する フッ素イオンの移動を妨げることに関連していると推察 される.

本研究を行なうに当り研究費の一部は鉄鋼基礎共同研 究会特殊精鍊部会の援助を付記すると共に討論ならびに 有益なコメントをたまわつた同部会第 4 分科会委員各位 に感謝します。

\section{交献}

1) 荻野和巳，橋本英弘，原茂太：鉄と鋼，投稿中

2 ) 荻野和巳，原茂太：鉄と鋼，投稿中

3 ) I. BaAk: Acta Chem. Scand. 9 (1955), No. 8, p. 1406

4 ) P. P. Evseev: Avtomat. Svarka (1967) No. 11, p. 42

5 ) H. Zmoidin: Izvest. Akad. Nauk SSSR (1970) No. 3, p. 71

6 ) $H$. Winterhaher, $R$. Kammel and $A$. Gad: Forschungs berichte des Landes NorderheinWestfalen, (1970), Nr. 2115

7 ) $A$. Mitchell and $S$. Joshi: Met. Trans., 3 (1972) No. 8, p. 2306

8 ）荻野和巳，原茂太：鉄と鋼，投稿中

9 ) J. W. Tomlinson, A. F. Heyes and J.O. M Bockris: Trans. Faraday Soc. 54 (1958), p. 1822

10) P. P. Evseev and $A \cdot F$. Filippov: Izv. VUZov. Chern. Met. (1967) No. 5, p. 49

11) $H$. Kojima and $C . R$. MAsson: Canadian J. Chem. 47 (1969), p. 4221

12) R. IV. URe Jr.: J. Chem. Phy., 26 (1957) No. 6, p. 1363

13) W. Klemm and $W$. Biltz: Z. Anorg. Allgem. Chem. 152 (1926), p. 255, 267

14）伊藤勝久，中村英次：住友軽金属技報，17 (1976) No. 1 2, p. 61

15) H. Bloom: The Chemistry of Molten Salts, (1967), [Benjamin]

16) W. E. Duckworth and G. Hoyle: Electroslag Refining, (1969), [Chapman and Hall]

17) I. S. YAffe and E. R. VAn Artsdalen: J. Phys. Chem., 60 (1956), p. 1125

18) G. J. JANZ: Molten Salts Handbook, (1967), [Academic Press]

19) J. O. M Bockris, $J . A$. Kitchener, $S$. Ignatowicz and $J . W$. Tomlinson: Trans. Faraday Soc., 48 (1952), p. 75 